\title{
Effect of Temperature on the Electrical Resistance and Voltage Departures (Errors) of Glass Electrodes, and Upon the Hygroscopicity of Glass
}

\author{
Donald Hubbard
}

\begin{abstract}
The effect of temperature upon the electrical resistance and $\mathrm{pH}$ response has been studied on electrodes prepared from three types of glasses: Pyrex 7740, commercial softglass tubing, and Corning 015; glasses of low, intermediate, and high hygroscopicity, respectively. The results show that electrical resistance is not the determinant in most cases of voltage departure from the theoretical, and in the inherent failure of many glasses to act as satisfactory indicators of hydrogen-ion activity of aqueous solutions. For example, the electrodes prepared from Pyrex glass gave no significant $\mathrm{pH}$ response even when the resistance was as low as 12 megohms. The results of electrodes from glasses of intermediate hygroscopicity gave a pseudo-correspondence of $\mathrm{pH}$ response with resistance, whereas electrodes of Corning 015 gave voltage departures that could in no way be attributed to the electrical resistance of the electrode.
\end{abstract}

\section{Introduction}

Considerable confusion exists in the general concept as to what part the electrical resistance of a glass electrode plays in its voltage response to hydrogen-ion activity of aqueous solutions, the voltage departures (errors) that appear at high alkalinities and in the "superacid" region, and particularly in the failure of electrodes from many glasses to follow the simple dictates of the Nernst equation, $\Delta E=$ $0.000198 T \Delta \mathrm{pH}$. For example, the difference in performance shown between electrodes from Pyrex 7740 and a satisfactory pH-responsive glass (fig. 1) is presumed to be related somehow to a difference in resistance of the glass membranes forming the effective portion of the electrode. With the electrometer tubes available requiring grid currents of only $10^{-12}$ to $10^{-15}$ amp, a glass electrode having a resistance as great as 1,000 megohms would exhibit an IR drop (error) ranging from $10^{-3}$ to $10^{-6} \mathrm{v}[1$, pages 47 and 89 to 92$]^{1}$ Such errors are small, and for most practical $\mathrm{pH}$ measurements can be disregarded. It is obvious that glass electrodes exhibiting large voltage departures, $\mathrm{pH}$ errors, but having resistances less than 1,000 megohms, are failing to show full $\mathrm{pH}$ response not because of their high electrical resistance nor because of a lack of sensitivity of the available indicating electrometers.

The present investigation was undertaken to ascertain what individual parts the hygroscopicity (water sorption) of the glass and the electrical resistance of the glass membrane play in the over-all picture of the ability, or lack of ability, of electrodes from various glasses to act as indicators of hydrogenion activity of aqueous solutions over the temperature range $20^{\circ} \mathrm{C}$ to near the boiling point of water.

\section{Experimental Procedures}

The hygroscopicity values were obtained in the apparatus described in previous publications [2].
The experiments at elevated temperatures were carried out by immersing the humidity chamber in a thermostated water bath. Although no mechanical difficulties were encountered, this procedure for obtaining hygroscopicity was not entirely satisfactory, because of excessive condensation on the walls of the chamber at the elevated temperatures for the high humidity (approximately 98 percent) required for the experiments. However, the results appeared to be qualitatively acceptable. The hygroscopicity values reported are those obtained for 1-hour exposures.

The voltage performance of any experimental electrode was determined by the voltage change that appeared when the cell consisting of the experimental electrode and a reference electrode was transferred from a buffer solution at $\mathrm{pH} 4.1$ to a buffer at $\mathrm{pH} 8.2$. The reference electrode employed was either a hydrogen electrode or a glass electrode calibrated at the elevated temperatures. Thus if the experimental electrode gave full $\mathrm{pH}$ response, no change in voltage appeared in the two buffers at any temperatures. Typical examples of the data obtained by this procedure are illustrated in figure 1 for a commercial electrode and one prepared from Pyrex glass 7740 The above $\mathrm{pH}$ interval was chosen because it is a region of uniform chemical durability of the glasses studied [3]. Thus, voltage shifts are eliminated or minimized, which might be credited to a change in chemical durability [2]. The calibrated mercuryfilled glass electrode [4] was preferred over the hydrogen electrode as a reference electrode because of operational simplicity and ease of temperature control by eliminating the hydrogen-gas chain. Furthermore, with both the reference and experimental electrodes filled with mercury, any small thermoelectric voltages generated at the $\mathrm{Pt}-\mathrm{Hg}$ junction would be compensated by the symmetry of the system. All electromotive-force measurements were made with a Beckman $\mathrm{pH}$ meter, laboratory model G.

The resistance values for the experimental glass electrodes were followed at the different tempera- 


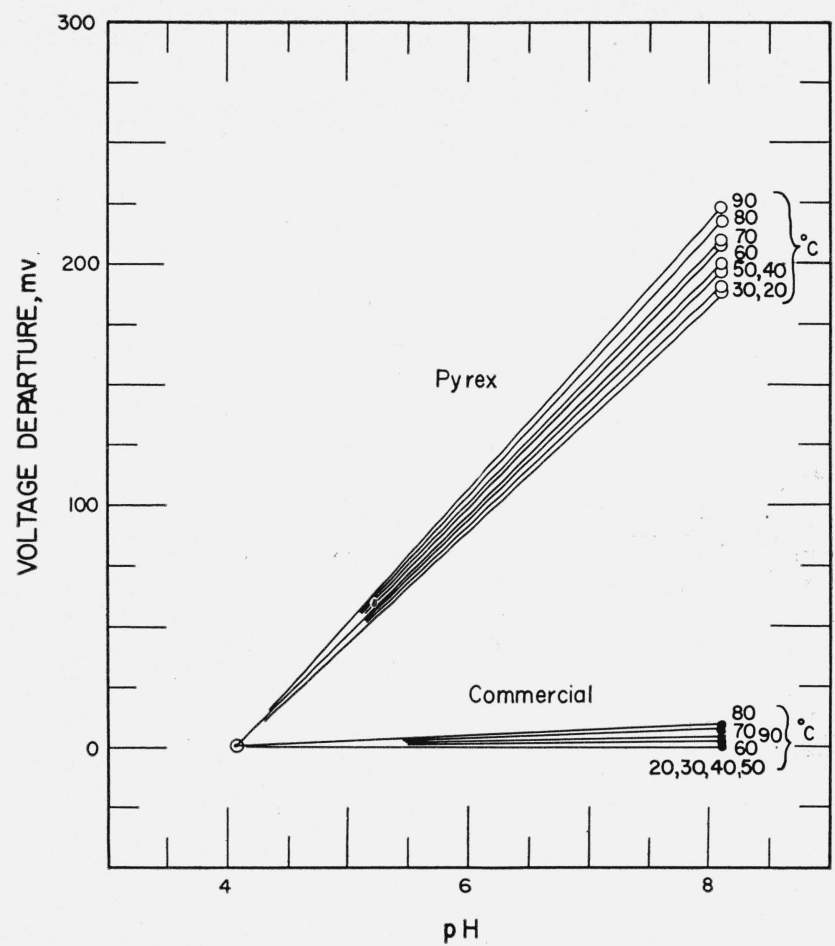

Figure 1. Voltage departures at various temperatures observed over the interval $\mathrm{pH} 4.1$ to $\mathrm{pH} 8.2$ for two glass electrodes, one of which was a commercial glass-electrode and the other prepared from Pyrex glass 7740 .

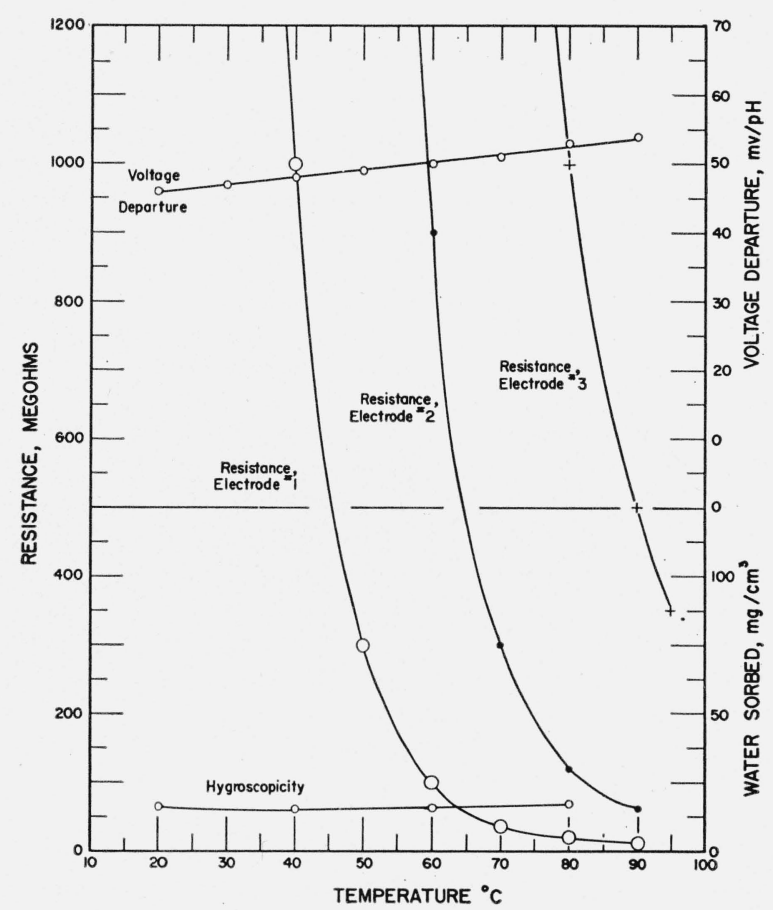

FIGURE 2. Effect of temperature upon the resistance, hygroscopicity, and $p \mathrm{H}$ response of electrodes prepared from Pyrex glass 7740 , a glass of low hygroscopicity. tures with an RC.A Senior Voltohmyst TWV-97 A, which imposes $1.5 \mathrm{~V}$ across the glass membrane, while the bulb of the electrode was immersed in Britton universal buffer at $\mathrm{pH}$ 4.1. The electrical connections for these measurements were established by means of platinum leads, one of which was dipped into the buffer solution and the other into the mercury filling the glass electrode bulb. A number of parallel observations were made with a General Radio type 544-BS8 megohm bridge operating with $100-v$ drop across the terminals, to make sure that neither polarization nor the voltage generated by the battery, consisting of the two cells, glass electrode, and platinum wire, was causing spurious resistance values to be reported [5]. The higher voltage of the megohm bridge might cause polarization resistance at the glass surface or even puncture the glass membrane, whereas the low operation voltage of the Voltohmyst might be seriously affected by counter voltage generated by the battery consisting of the glass electrode and the external platinum-wire connection. Because the two instruments indicated approximately the same resistance, it seemed reasonably sure that the effects of polarization and interfering voltages were not large.

\section{Results and Discussions}

\section{1. Electrodes Prepared from Pyrex Glass 7740; A Glass of Low Hygroscopicity}

Figure 2 and table 1 show the effect of temperature upon the electrical resistance and $\mathrm{pH}$ response of electrodes prepared from the sample of Pyrex 7740, chemical-ware glass, and the hygroscopicity of this glass over the same temperature range. The resistance curves for these three electrodes are in accord with the long known fact that the electrical resistivity of glass decreases rapidly as the temperature is increased and follows in a general way the exponential equation

$$
R=B e^{A / T},
$$

where

$R=$ the resistivity,

$B=$ a constant,

$A=$ a constant involving the activation energies,

$T=$ temperature,

$e=2.71828$, the limit of the series $(1+1 / n)^{n}$ as $n \doteq \infty[6]$.

At times the resistance curve obtained experimentally may depart conspicuously from this shape; typical examples obtained on an electrode are illustrated by $\mathrm{A}$ and $\mathrm{B}$ in figure 3 . Such $\mathrm{S}$ curves can be readily accounted for qualitatively by electrical surface leakage under conditions in which the resistance of the electrode bulb becomes increasingly great in comparison to the surface resistance of the glass tube. The total resistance, $R$, of the two con- 


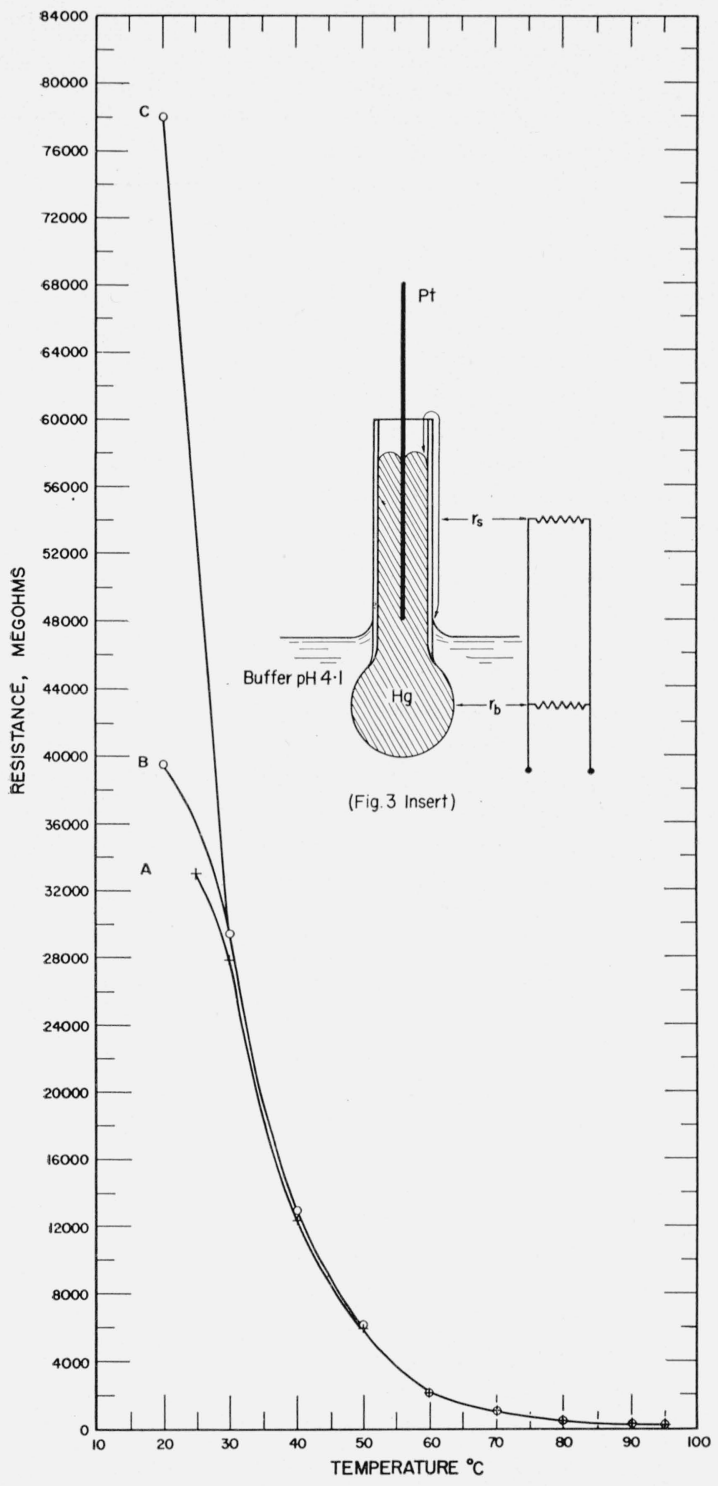

Figure 3. Resistance values obtained on a single glass electrode illusirating the effect of surface conductivity upon the shape of the resistance-temperature curves.

Curves $\mathrm{A}$ and $\mathrm{B}$ were obtained before surface trcatment; $\mathrm{C}$, after cleaning and drying. Insert is a schematic diagram illustrating the resistances involved. $r_{s}=$ surface resistance, $r_{b}=$ resistance of the glass electrode

ductors, electrode bulb and glass surface in parallel (fig. 3 insert), whose separate resistances are $r_{b}$ and $r_{s}$, is given by the relation

$$
1 / R=1 / r_{b}+1 / r_{s}, \text { or } R=\frac{r_{b} r_{s}}{r_{b}-r_{s}} .
$$

As $r_{b}$ becomes so very large as to approximate the resistance of an open circuit, $R$ approaches $r_{s}$ as a limiting value

$$
1 / R=1 / \infty+1 / r_{\mathrm{s}}, \quad \text { or } \quad R=r_{s} .
$$

These $\mathrm{S}$ curves are readily brought back into conformity by cleaning, drying, or treating the surface
TABLE 1. Characteristic resistance, voltage departure, and hygroscopicity values observed at different temperatures for electrodes prepared from glasses of high, intermediate, and

\begin{tabular}{|c|c|c|c|c|}
\hline \multicolumn{5}{|c|}{ Corning 015 electrode } \\
\hline No. & $\begin{array}{l}\text { Temper- } \\
\text { ature }\end{array}$ & $\begin{array}{l}\text { Water } \\
\text { sorbed }\end{array}$ & $\begin{array}{l}\text { Voltage } \\
\text { departure }\end{array}$ & $\begin{array}{l}\text { Electrical } \\
\text { resistance }\end{array}$ \\
\hline 3 & 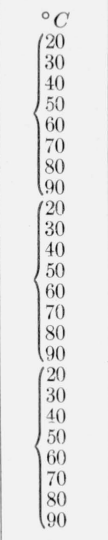 & $\begin{array}{c}\begin{array}{c}\mathrm{mg} / \mathrm{cm}^{3} \\
105\end{array} \\
112 \\
131 \\
144 \\
105 \\
112 \\
131 \\
144 \\
105 \\
112 \\
131 \\
144 \\
\end{array}$ & $\begin{array}{c}m v / p H \\
0 \\
0 \\
0 \\
0 \\
0 \\
0 \\
0 \\
0 \\
5 \\
4 \\
3 \\
2 \\
1- \\
0 \\
0 \\
0 \\
42 \\
32 \\
19 \\
12 \\
8- \\
8.5 \\
8.5 \\
9.5\end{array}$ & $\begin{array}{c}\text { Megohms } \\
115 \\
48 \\
19 \\
9.3 \\
4.8 \\
2.5 \\
1.1 \\
0.59 \\
495 \\
225 \\
120 \\
59 \\
33 \\
17 \\
9.3 \\
5.8 \\
950 \\
500 \\
250 \\
110 \\
45 \\
21 \\
10 \\
5.2\end{array}$ \\
\hline \multicolumn{5}{|c|}{ Soft-glass electrode } \\
\hline 1 & $\begin{array}{l}\left\{\begin{array}{l}20 \\
30 \\
40 \\
50 \\
60 \\
70 \\
80 \\
90 \\
20 \\
30 \\
40 \\
50 \\
60 \\
70 \\
80 \\
90\end{array}\right.\end{array}$ & $\begin{array}{c}26 \\
36 \\
53 \\
87 \\
26 \\
36 \\
53 \\
87 \\
5\end{array}$ & $\begin{array}{r}0 \\
0 \\
0 \\
0 \\
0 \\
0 \\
0 \\
0 \\
-52 \\
36 \\
15 \\
1 \\
0 \\
0 \\
0\end{array}$ & $\begin{array}{r}8,300 \\
3,800 \\
1,800 \\
950 \\
350 \\
120 \\
41 \\
16 \\
31,000 \\
12,000 \\
5,390 \\
2,490 \\
1,110 \\
455 \\
207\end{array}$ \\
\hline \multicolumn{5}{|c|}{ Pyrex 7740 electrode } \\
\hline 1 & 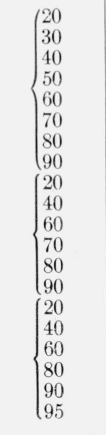 & \begin{tabular}{c}
17 \\
15 \\
16 \\
17.5 \\
17 \\
15 \\
16 \\
17.5 \\
17 \\
15 \\
16 \\
17.5 \\
\hdashline-
\end{tabular} & $\begin{array}{l}46 \\
47 \\
48 \\
49 \\
50 \\
51 \\
53 \\
54 \\
- \\
- \\
- \\
- \\
- \\
\\
\\
\\
\\
\\
\\
\end{array}$ & $\begin{array}{c}5,800 \\
2,300 \\
1,000 \\
300 \\
99 \\
35 \\
19 \\
12 \\
\cdots \cdot- \\
-900 \\
300 \\
120 \\
61 \\
-\cdots \\
\cdots-\cdot- \\
1,000 \\
500 \\
350\end{array}$ \\
\hline
\end{tabular}
low hygroscopicity

of the glass stem with appropriate water repellants, such as paraffin, organic chlorosilanes, or commercial Desicote [6].

The voltage-departure characteristics of electrode 1 as affected by temperature are also plotted in figure 2. From this curve it is evident that there was no improvement in the $\mathrm{pH}$ response of this Pyrex electrode, although the resistance fell to such low values as $99,35,19$, and 12 megohms. In other words, the low resistance was not accompanied by a correspond- 
ing improvement in $\mathrm{pH}$ response. Electrodes 2 and 3 were checked at $30^{\circ}$ and $90^{\circ} \mathrm{C}$ and were also found to be unresponsive to the $\mathrm{pH}$ of the buffer solutions. Obviously, if electrical resistance were the major determinant in $\mathrm{pH}$ response of this glass, the three Pyrex electrodes would be expected to develop improved response at different temperatures in accord with their resistance curves. However, they are all useless as indicators of hydrogen-ion activity. Only upon a study of the hygroscopicity curve obtained on Pyrex glass does one get a plausible reason for the complete indifference of these electrodes to the lowered resistance at the elevated temperatures (fig. 2 ). The water sorbed by the glass has not changed appreciably with the increase in temperature and does not at any temperature approach a value commensurate with an effective electrode glass. [5, 7] Certainly the lowered resistance can not be attributed to water penetrating the glass. As a result, the voltage departure of the electrode in $\mathrm{mv} / \mathrm{pH}$ becomes greater with increased temperature. This increased departure is largely the result of the temperature effects inherent in the derivation of the Nernst equation. Based on previous evidence, the electrodes prepared from this nonhygroscopic glass probably would have no satisfactory $\mathrm{pH}$ response, regardless of how thin the glass membranes were blown $[5,8,9]$.

\subsection{Electrodes Prepared from a Glass of Intermediate Hygroscopicity}

Figure 4 shows the effect of temperature on the resistance and $\mathrm{pH}$ characteristics of two glass electrodes prepared from a commercial soft glass of intermediate hygroscopicity. The performance of these

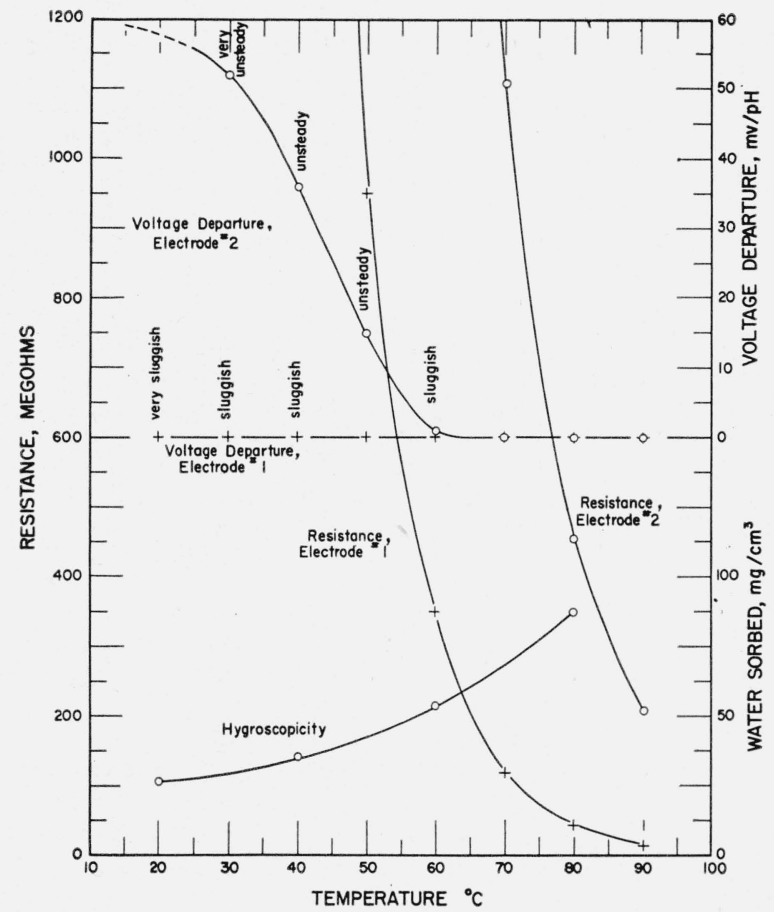

FIGURE 4. Effect of temperature upon the electrical resistance, hygroscopicity, and $\mathrm{pH}$ response of electrodes prepared from a glass of intermediate hygroscopicity. electrodes more nearly follows the general conception of the part that resistance should play in determining the suitability of a glass for $\mathrm{pH}$ measurements. Electrode 1 at $20^{\circ} \mathrm{C}$ was very sluggish in drifting toward a steady voltage, whereas at $30^{\circ}$ and $40^{\circ} \mathrm{C}$ the performance was still sluggish, but markedly improved. Above $50^{\circ} \mathrm{C}$ the resistance of the bulb fell rapidly below 1,000 megohms, and the electrode performed in an acceptable manner for high-temperature $\mathrm{pH}$ measurements. As the chemical durability of this glass is far superior to that of Corning 015 . the life expectancy of electrodes prepared from it when used for high-temperature $\mathrm{pH}$ measurements would be correspondingly greater $[1,10,11]$. Electrode 2 was blown with a bulb considerably thicker than electrode 1. At $30^{\circ} \mathrm{C}$ the voltage departure was large and very unsteady. This electrode showed marked improvement, but was still unserviceable at $40^{\circ}$ and $50^{\circ} \mathrm{C}$. The voltage departures were small at $60^{\circ}$ and $70^{\circ} \mathrm{C}$, but the electrode performance was still sluggish. Beyond $80^{\circ} \mathrm{C}$, the resistance of the bulb had fallen well below 1,000 megohms, and the over-all performance of the electrode was acceptable. As the $\mathrm{pH}$ response of these electrodes improved with decrease in resistance, a correlation of the $\mathrm{pH}$ response with the resistance values would apparently be acceptable, but not entirely adequate, as will be seen from the discussion and evaluation of the data in figure 7. However, the shape of the hygroscopicity-temperature curve is entirely different from that of Pyrex and probably is equally satisfactory in accounting for the improved performance of the glass electrode. (Compare the hygroscopicity curves in fig. 2 and 4 .)

\subsection{Electrodes from Corning 015}

Figure 5 shows the electrical resistance and voltage performance of three electrodes prepared from a single sample of Corning 015 glass. Electrode 1 had low resistance values at all temperatures, ranging from 115 megohms at $20^{\circ} \mathrm{C}$ to 0.59 megohm at $90^{\circ} \mathrm{C}$. Having been prepared from a glass of relatively high hygroscopicity and of uniform chemical durability over the $\mathrm{pH}$ interval chosen, this thin-walled electrode gave satisfactory performance (approximating the theoretical) over the temperature range from $20^{\circ}$ to $90^{\circ} \mathrm{C}$. Electrode 2 was blown from the same length of glass tubing as electrode 1 , but with much heavier wall thickness. The resistance curve for this electrode fell below 500 megohms at $20^{\circ} \mathrm{C}$ and showed the usual rapid decline with increased. temperature. However, this thicker electrode exhibited appreciable voltage departure at all temperatures up to $70^{\circ} \mathrm{C}$, beyond which temperature it paralleled the performance of the reference electrode. Electrode 3, with a wall thickness in excess of $1 \mathrm{~mm}$, still had resistance values lower than many satisfactory electrodes, but gave voltage departures over the entire temperature range from $20^{\circ}$ to $90^{\circ} \mathrm{C}$. This performance is in accord with the general knowledge that every glass has a critical thickness at which voltage departures appear [8]. Such failures of an electrode to respond to hydrogen-ion activity certainly cannot be attributed to electrical resistance 


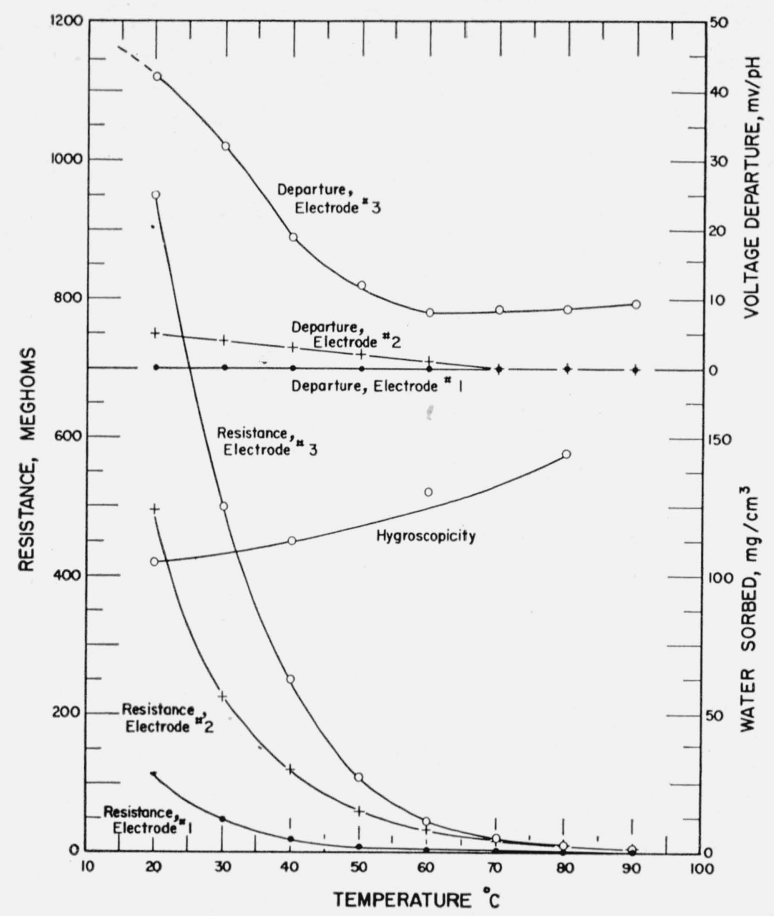

Figure 5. Effect of temperature upon the electrical resistance, hygroscopicity, and $\mathrm{pH}$ response of electrodes prepared from Corning 015, a glass of high hygroscopicity.

of the electrode, because at all temperatures the resistance is at values far below that at which the IR drop across the membrane would be as great as $1 \mathrm{mv}$. Possibly proton or $\mathrm{H}_{3} \mathrm{O}^{+}$resistance due to the thickness of the membrane, lack of water penetration of the glass, or a combination of both, give a more acceptable concept. It seems probable that the glass-water-hydrogen-ion-activity equilibrium does not become established throughout the glass, even though the inherent hygroscopicity of the glass is high (fig. 5).

In order to further emphasize the lack of universal correspondence between voltage departures of glass electrodes and electrical resistance of the glass membrane, resistance values were determined for an electrode of Corning 015 over an extended $\mathrm{pH}$ range (conc. $\mathrm{H}_{2} \mathrm{SO}_{4}$ to $\mathrm{pH} 12$ ) for temperatures from $20^{\circ}$ to $90^{\circ} \mathrm{C}$, and the results considered in relation to a conventional voltage departure curve obtained at room temperature over the same $\mathrm{pH}$ range (table 2 , fig. 6). These results show that the voltage departures in the high alkaline and superacid ranges are not attributable to excessively high electrical resistances, nor are they associated with marked changes in electrical resistance. Their causes have been discussed elsewhere in connection with the water activity of the solutions [1], chemical durability of the glass [2], heterogeneous equilibria at the glass electrode solution interface [15], and equilibrative response to ions other than hydrogen $[1,16]$.

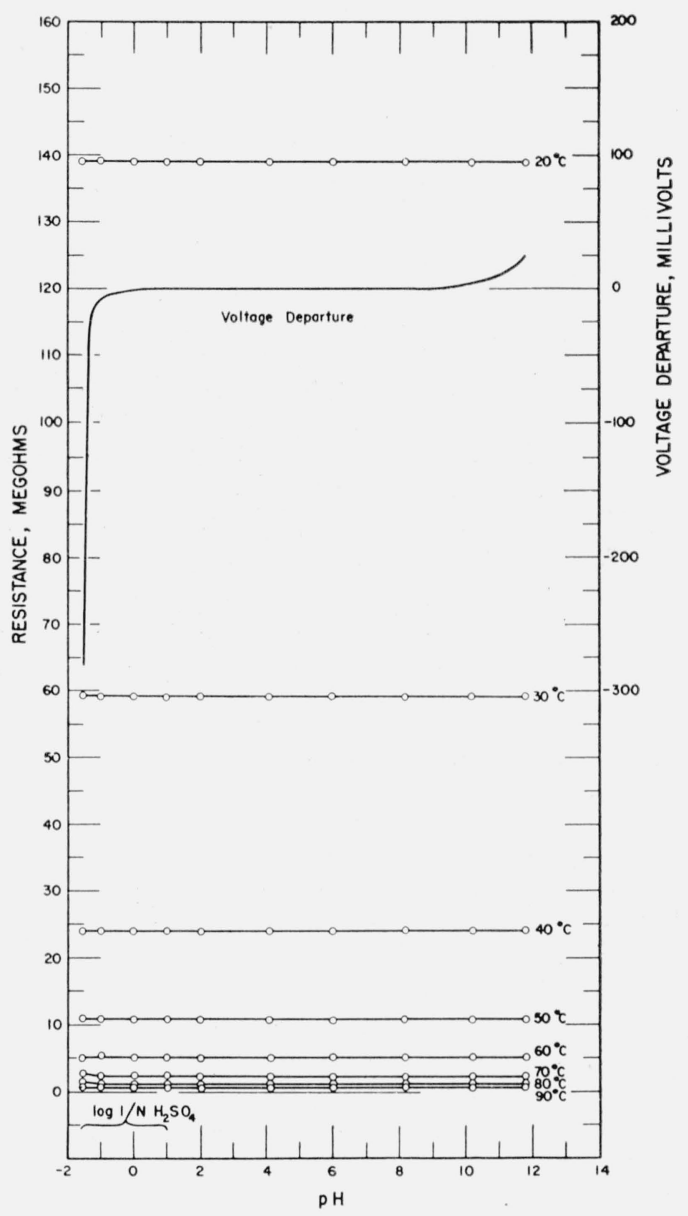

Figure 6. The pH-resistance curves obtained on an electrode of Corning 015 over an extended $\mathrm{pH}$ range (conc. $\mathrm{H}_{2} \mathrm{SO}_{4}$ to $\mathrm{pH}$ 12) for temperatures from $20^{\circ}$ to $90^{\circ} \mathrm{C}$, compared with a typical voltage departure (error) curve over the same $\mathrm{pH}$ range.

TABLE 2. Resistance values obtained for an electrode of Corning 015 over an extended $\mathrm{pH}$ range for temperatures from $20^{\circ}$ to $90^{\circ} \mathrm{C}$

\begin{tabular}{|c|c|c|c|c|c|c|c|c|c|c|}
\hline \multirow{3}{*}{ Temperature } & \multicolumn{10}{|c|}{ Resistance in- } \\
\hline & \multicolumn{4}{|c|}{$\mathrm{H}_{2} \mathrm{SO}_{4}$} & \multicolumn{6}{|c|}{ Britton buffers at $\mathrm{pH}-$} \\
\hline & $36 N$ & $10 N$ & $1 N$ & $0.1 N$ & 2 & 4.1 & 6.0 & 8.2 & 10.2 & 11.8 \\
\hline $\begin{array}{l}{ }^{\circ} \mathrm{C} \\
20 \\
30 \\
40 \\
50 \\
60\end{array}$ & $\begin{array}{c}\text { Megohms } \\
138 \\
59.4 \\
24 \\
10.8 \\
5 \text { to } 5.3\end{array}$ & $\begin{array}{c}\text { Megohms } \\
139 \\
59.2 \\
24 \\
10.7 \\
5.1\end{array}$ & $\begin{array}{c}\text { Megohms } \\
139 \\
59 \\
24 \\
10.7 \\
5\end{array}$ & $\begin{array}{c}\text { Megohms } \\
139 \\
59 \\
24 \\
10.7 \\
5\end{array}$ & $\begin{array}{c}\text { Megohms } \\
139 \\
59.2 \\
23.9 \\
10.7 \\
5\end{array}$ & $\begin{array}{c}\text { Megohms } \\
139 \\
59.2 \\
24 \\
10.7 \\
5\end{array}$ & $\begin{array}{c}\text { Megohms } \\
139 \\
59.2 \\
24 \\
10.7 \\
5\end{array}$ & $\begin{array}{c}\text { Megohms } \\
139 \\
59.1 \\
24 \\
10.6 \\
5\end{array}$ & $\begin{array}{c}\text { Megohms } \\
139 \\
59.2 \\
24 \\
10.7 \\
5\end{array}$ & $\begin{array}{c}\text { Megohms } \\
139 \\
59.2 \\
24 \\
10.7 \\
5\end{array}$ \\
\hline $\begin{array}{l}70 \\
80 \\
90\end{array}$ & $\begin{array}{l}2.39 \text { to } 2.7 \\
1.21 \text { to } 1.42 \\
.60 \text { to } .72\end{array}$ & $\begin{array}{l}2.3 \\
1.19 \\
.59\end{array}$ & $\begin{array}{l}2.3 \\
1.19 \\
.57\end{array}$ & $\begin{array}{r}2.29 \\
1.20 \\
.57\end{array}$ & $\begin{array}{r}2.29 \\
1.19 \\
.57\end{array}$ & $\begin{array}{r}2.27 \\
1.19 \\
.58\end{array}$ & $\begin{array}{r}2.29 \\
1.19 \\
.57\end{array}$ & $\begin{array}{l}2.3 \\
1.19 \\
.57\end{array}$ & $\begin{array}{r}2.27 \\
1.19 \\
.57\end{array}$ & $\begin{array}{r}2.27 \\
1.19 \\
.57\end{array}$ \\
\hline
\end{tabular}




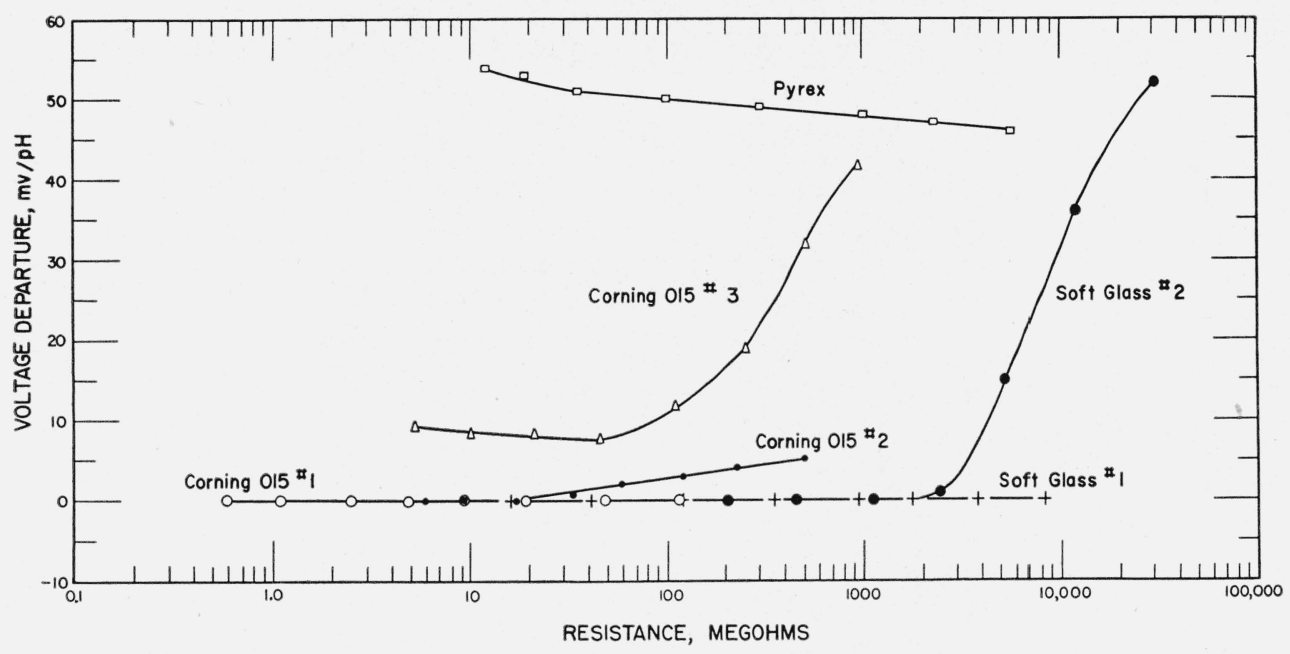

Figure 7. Comparison of the voltage departure and electrical resistance values of electrodes prepared from Corning 015, a commercial soft-glass tubing, and $P y$ rex glass 7740 .

The resistance sequence for each of the electrodes was produced by varying the temperature.

\subsection{Hygroscopicity versus Temperature}

Although the hygroscopicity curves for the three glasses reported must be classified as being of uncertain reliability, they do warrant a brief evaluation. If adsorption were the major factor contributing to the water sorbed, the hygroscopicity curves should decrease with increased temperature [12]. As the curves for two of the glasses, figures 4 and 5, show a liberal increase with temperature, it is obvious that absorption and reaction are predominating factors.

\section{Summary}

Figure 7 , in which the voltage departures (errors) are plotted as the dependent variable and resistance as the determinant, illustrates the incongruous part played by electrical resistance in the over-all picture of the $\mathrm{pH}$ response of glass electrodes. Not only do the $\mathrm{pH}$ response-resistance curves for electrodes from different glasses not coincide, but curves for electrodes from the same length of tubing (Corning 015 and soft-glass tubing) fail to exhibit similar characteristics. From the present investigation the part played by electrical resistance in determining the effectiveness of a glass for use as glass electrodes seems to be largely superficial. For example, electrodes prepared from glasses of low hygroscopicity, such as Pyrex, do not develop a staisfactory $\mathrm{pH}$ function even at very low resistance values. Furthermore, electrodes from glasses of high hygroscopicity and low resistance, such as Corning 015, fail to give full response to hydrogen-ion activity if the membrane thickness is excessive. From the data on the above two glasses, plus the results obtained on a glass of intermediate hygroscopicity, it appears that resistance values below 1,000 megohms are desirable, but certainly not sufficient to bring about staisfactory $\mathrm{pH}$ response.

Voltage departures from the theoretical $\mathrm{pH}$ response can appear for glass electrodes of low electrical resistance for the following reasons:

1. Low hygroscopicity of the glass from which the electrode is prepared $[2,7]$.
2. Membrane walls greater than a limiting thickness value, which differs for every glass [8].

3. Poor chemical durability of the glass [2]

4. High concentration of electrolytes [13, 14, 15].

5. Inhibiting films [9].

\section{References}

[1] Malcolm Dole, The glass electrode (John Wiley \& Sons, Inc., New York, N. Y., 1951).

[2] Donald Hubbard, Mason H. Black, Sylvanus F. Hollev, and Gerald F. Rynders, Electrode function ( $\mathrm{pH}$ response), hygroscopicity, and chemical durability of soda-potash-silica glasses, J. Research NBS 46, 168 (1951) RP2189.

[3] Donald Hubbard and Edgar H. Hamilton, Studies of the chemical durability of glass by an interferometer method, J. Research NBS $2 \%, 143$ (1941) RP1409.

[4] M. R. Thompson, A metal-connected glass electrode, BS J Research 9, 833 (1932) RP511.

[5] Richard G. Goldman and Donald Hubbard, pH response of nonhygroscopic glasses, J. Research NBS 48, 370 (1952) RP2324.

[6] J. E. Stanworth, Physical properties of glass (Oxford University Press, Oxford, England, 1950).

[7] Donald Hubbard, Hygroscopicity and electrode function (pH response) of glasses as a measure of serviceability, J. Research NBS 36, 511 (1946) RP1719.

[8] J. J. Diamond and Donald Hubbard, Thickness of glass electrodes, J. Research NBS 47, 443 (1951) RP2270.

[9] Donald Hubbard and Gerald F. Rynders, Thickness of inhibiting films on glass electrode surfaces, J. Research NBS 41, 163 (1948) RP1915.

[10] Henry H. Cary and Warren P. Baxter, U. S. Patent 2383709 (1945).

[11] George A. Perley, Composition of $\mathrm{pH}$-responsive glasses, Anal. Chem. 21, 391 (1949).

[12] Herbert Freundlich, Colloid and capillary chemistry (E. P. Dutton \& Co., Inc., New York, N. Y.).

[13] D. A. MacInnes and D. Belcher, Further studies on the glass electrode, J. Am. Chem. Soc. 53, 3315 (1931).

[14] Donald Hubbard and Gerald F. Rynders, Voltage anomalies of the glass electrode and the chemical durability of the glass, J. Research NBS 39, 561 (1947) RP1848.

[15] Donald Hubbard and Richard G. Goldman, Heterogeneous equilibria at the glass electrode-solution interface, J. Research NBS 48, 428 (1952) RP2333.

[16] B. Lengyel and E. Blum, The behavior of the glass electrode in connection with its chemical composition. Trans. Faraday Soc. 30, 461 (1934).

Washington, April 9, 1953. 